\title{
PENGEMBANGAN MEDIA SMART EXPLODING BOX BERBASIS DEEP DIALOGUE CRITICAL THINKING UNTUK MENGHADAPI ERA REVOLUSI INDUSTRI 4.0
}

\author{
Feri Tirtoni' $^{1}$, Fidaus Su'udiyah ${ }^{2}$, Joko Susilo ${ }^{3}$ \\ feri.tirtoni@umsida.ac.id ${ }^{1}$, suuphierhero@umsida.ac.id ${ }^{2}$, jokosusilo1@umsida.ac.id ${ }^{3}$ \\ Prodi PGSD, FPIP, Universitas Muhammadiyah Sidoarjo ${ }^{12}$ \\ Prodi Manajemen, Fakultas Ekonomi, Universitas Muhammadiyah Sidoarjo ${ }^{3}$
}

\begin{abstract}
Abstrak : Penelitian ini bertujuan untuk : (1) menguji kevalidan media smart exploding box berbasis deep dialogue critical thinking beserta perangkatnya (silabus dan rencana pelaksanaan pembelajaran (RPP), buku ajar PKn berbasis deep dialogue critical thinking, dan tes hasil belajar (THB)); (2) Mengukur tingkat aktivitas siswa melalui penggunaan media tersebut; (3) Mengukur kemampuan berfikir kritis siswa setelah penggunaan media tersebut, dan (4) mengukur respon minat siswa setelah penggunaan media tersebut. Metode penelitian yang dilakukan menggunakan model pengembangan Plomp (dalam Khabibah, 2006) yang terdiri dari: (1) Investigasi awal, (2) Desain, (3) Realisasi/konstruksi, (4) Pengujian, Evaluasi, dan Revisi, (5) Implementasi. Dari hasil dan pembahasan pada bagian di atas, disimpulkan bahwa, media dan perangkat pembelajaran yang dikembangkan pada penelitian ini termasuk dalam kategori valid, dimana hasil kevalidan ahli media mendapatkan skor 25 (baik) dan ahli materi mendapatkan skor 24 (baik). Berdasarkan hasil uji coba pada pertemuan ke-1 dan ke-2 yang telah dilaksanakan pada penelitian ini ditemukan sebuah data baru bahwa penggunaan media ini pada mata pelajaran PKn pada kelas V SDN Ketajen I Sidoarjo menunjukkan bahwa hasil rerata persentase capaian aktivitas siswa satu kelas (7 aspek amatan selama 2 pertemuan) sangat tinggi, yaitu sejumlah $84 \%$. Kemudian data hasil TKBK sebesar 81,15 (tuntas). Selain itu, media ini juga mendapatkan respon minat siswa yang baik, yaitu pada pertemuan terakhir (ke-2) mendapatkan skor attention (perhatian) sebesar 17,5 (sangat baik), convidence (keyakinan) sebesar 11,0 (baik), satisfaction (kepuasan) sebesar 7,0 (cukup), dan relevance (keterkaitan) sebesar 8 (cukup).
\end{abstract}

Kata kunci : smart exploding box, dialogue and criical thinking, aktivitas, kemampuan berfikir kritis, minat

\section{DEVELOPMENT OF SMART EXPLODING BOX MEDIA BASED ON CRITICAL THINKING DIALOGUE TO FACE THE INDUSTRY 4.0 REVOLUTION}

Abstract: This study aims to: (1) test the validity of the smart exploding box based on deep dialogue critical thinking and its tools (syllabus and learning implementation plan, PKn textbook based on deep dialogue critical thinking, and learning achievement test); (2) Measuring the level of student activity through the use of the media; (3) Measuring students' critical thinking skills after the use of the media, and (4) measuring the response of students' interests after the use of the media. The research method carried out using the Plomp development model (in Khabibah, 2006) consisting of: (1) Initial investigations, (2) Design, (3) Realization / construction, (4) Testing, Evaluation, and Revision, (5) Implementation. From the results and discussion in the section above, it 
Feri, Fidaus, Joko. Pengembangan Media Smart Exploding...

was concluded that, the media and learning tools developed in this study were included in the valid category, where the results of the validity of media experts got a score of 25 (good) and material experts got a score of 24 (good). Based on the results of trials at the 1 st and 2nd learning meetings that have been carried out in this study found a new data that the use of this media in Civics subjects in class V SDN Ketajen I Sidoarjo showed that the average percentage of student achievement in one class (7) the observation aspect during 2 meetings) is very high, which is $84 \%$. Then the critical thingking test result data is 81.15 (complete). In addition, this media also received a good student interest response, namely at the last meeting (2nd) getting an attention score of 17.5 (very good), evidence of 11.0 (good), satisfaction (satisfaction) of 7.0 (enough), and relevance of 8 (enough).

Keywords: smart exploding box, dialogue and critical thinking, activity, critical thinking ability, interest

\section{PENDAHULUAN}

Peserta didik level sekolah dasar (SD) memiliki pola berfikir yang sangat unik, dunia mereka adalah hal yang bersifat nyata dan masih dalam pengenalan berfikir tingkat abstrak. Teori yang biasa digunakan untuk menganalisi fenomena ini adalah teori praoperasional kongkret yang dicetuskan oleh Piaget, dimana dinyatakan bahwa usia 7-12 tahun adalah masa dimana siswa belajar dari sesuatu yang dia lihat, dia dengar, dia rasakan, dia sentuh dalam aktifitas keseharian lingkungan mereka. Siswa dalam ranah demikian belajar dari pengalaman belajar yang penuh aktifitas kreatif baik di rumah maupun di sekolah (Sujana, 2005).

Pendidikan Kewarganegaran (PKn) merupakan pembelajaran yang membentuk karakter dan watak anak sehingga siswa dapat memecahkan masalah yang dihadapinya, akan tetapi dalam pembelajaran tidak hanya membentuk karakter dan watak anak tersebut, tetapi diperlukan juga membentuk kemampuan berpikir kritis, sehingga akan mendorong sikap menjadi lebih baik dan membentuk karakter yang kritis (Mastiono, 2016).

Latar belakang dan urgensi penelitian ini adalah tingkat berpikir kritis siswa SD di perkotaan khususnya Jawa Timur masih terbilang minim, yaitu hanya sebesar 20-26 $\%$ dari rata-rata siswa di dalam kelas yang mampu berfikir kritis saat PBM berlangsung, hal ini terjadi karena rendahnya keterampilan siswa dalam hal bertanya, menanggapi, mempresentasikan serta berdialog sesama siswa pada saat proses pembelajaran serta masih sulitnya dalam menyampaikan pendapat atau opsi jawaban kepada guru saat pembelajaran dan belum mampu memahami konsep abstrak pada pembelajaran pendidikan kewarganegaraan (Budi, 2017). 
Feri, Fidaus, Joko. Pengembangan Media Smart Exploding...

Kedepan tantangan di era revolusi industri 4.0 mewajibkan setiap individu memiliki keterampilan berfikir kritis dalam berbagai bidang yang multidisipliner. Dilapangan ditemukan kembali sebuah data dari permasalahan pada sisi rendahnya ketrampilan proses berpikir kritis siswa kelas V di SDN Ketajen I Sidoarjo, yaitu sebesar $72 \%$ siswa di kelas $\mathrm{V}$ mengalami kesulitan dalam proses berfikir kritis saat PBM dari total 28 siswa di dalam kelas. Data tersebut berdasarkan hasil observasi peneliti yang dilakukan pada tanggal 15 Oktober 2018. Maka dari Latar belakang permasalahan di atas diperlukan suatu cara untuk meningkatkan ketrampilan berpikir kritis siswa SD melalui pengembangan media smart exploding box berbasis deep dialogue critical thinking. Penelitian ini bertujuan untuk : (1) menguji kevalidan media smart exploding box berbasis deep dialogue critical thinking beserta perangkatnya ( silabus dan rencana pelaksanaan pembelajaran (RPP), buku ajar PKn berbasis deep dialogue critical thinking, dan tes hasil belajar (THB)); (2) Mengukur tingkat aktivitas siswa melalui penggunaan media tersebut; (3) Mengukur kemampuan berfikir kritis siswa setelah penggunaan media tersebut, dan (4) mengukur respon minat siswa setelah penggunaan media tersebut.

\section{METODE}

\section{Pendekatan Penelitian}

Jenis penelitian ini merupakan penelitian pengembangan karena peneliti akan mengembangkan suatu media box men jadi smart exploding box berbasis deep dialogue and critical thinking, dari pengembangan media box ini tujuannya untuk meningkatkan kemampuan berpikir kritis siswa SD kelas V mata pelajaran PKn. Pengembangan dalam penelitian yang dilakukan menggunakan model pengembangan Plomp (dalam Khabibah, 2006) yang terdiri dari: (1) Investigasi awal, (2) Desain, (3) Realisasi/konstruksi, (4) Pengujian, Evaluasi, dan Revisi, (5) Implementasi.

\section{Sasaran Penelitian}

Sasaran Objek penelitian pengembangan dalam penelitian ini adalah media smart exploding box berbasis deep dialogue and critical thinking. Untuk sasaran subjek dalam penelitian pengembangan media smart exploding box berbaisis depp dialogue and critical thinking adalah siswa kelas V SDN Kejaten I Sidoarjo. 
Feri, Fidaus, Joko. Pengembangan Media Smart Exploding...

\section{Lokasi Penelitian}

Lokasi penelitian pengembangan media smart exploding box berbasis deep dialogue and critical thinking dilakukan di SDN Kejaten I Sidoarjo kelas V.

\section{Instrumen Penelitian dan Teknik Pengumpulan Data}

Instrumen penelitian merupakan suatu alat yang digunakan untuk mengukur fenomena sosial maupun fenomena alam. Instrumen penelitian yang diperlukan pada penelitian ini ada empat jenis, yaitu (1) lembar validasi, (2) lembar observasi penggunaan media smart exploding box berbasis deep dialogue and critical thinking, (3) lembar Tes Kemampuan Berpikir Kritis Siswa (TKBK), dan (4) lembar respons minat siswa. Berikut dijelaskan secara rinci tahap-tahap dalam penelitian pengembangan yang dilakukan dalam pengembangan instrumen :

\section{Lembar Validasi Media Smart Exploding Box Berbasis Deep Dialogue and Critical}

\section{Thinking dan perangkat pendukungnya}

Lembar validasi ini digunakan untuk memperoleh data tentang kevalidan media smart exploding box berbasis deep dialogue and critical thinking dan perangkat pendukungnya oleh validator mengenai aspek-aspek dan rancangan media serta perangkat pembelajaran, selanjutnya penilaian validator tersebut dijadikan pedoman peneliti untuk merevisi rancangan media dan perangkat pendukungnya (Budiningsih, 2010).

\section{Lembar Observasi Keaktifan Penggunaan Media Smart Exploding Box Berbasis} Deep Dialogue and Critical Thinking

Lembar observasi digunakan untuk mengamati aktivitas siswa saat menggunakan media smart exploding box berbasis deep dialogue and critical thinking. Aktivitas tersebut meliputi pembentukan kelompok, pembagian bagian media, pemilihan petunjuk-petunjuk sesuai bagian kelompoknya, bertanya, menjawab dan berdialog (Suoarman, 2014).

\section{Tes Kemampuan Berpikir Kritisf Siswa (TKBK)}

Tes Kemampuan Berpikir Kritis siswa ini dikembangkan berdasarkan komponen Memfokuskan, Mempertimbangkan, Mendefinisikan, Memutuskan. Tes Kemampuan Berpikir Kritis ini dinilai berdasarkan indikator berpikir kritis menurut Norris dan Ennis (2007). Tes Ketrampilan Berpikir Kritis ini diberikan kepada siswa 
Feri, Fidaus, Joko. Pengembangan Media Smart Exploding...

setelah siswa bermain serta menggunakan media smart exploding box berbasis deep dialogue and critical thinking materi keorganisasian sekolah dan masyarakat.

\section{Lembar Angket Respons Minat Siswa}

Angket respon yang dikembangkan yaitu angket respons siswa yang digunakan untuk mengumpulkan data tentang respon atau tanggapan terkait minat siswa terhadap media smart exploding box berbasis deep dialogue and critical thinking. Angket ini diberikan pada siswa setelah siswa melakukan aktivitas pembelajaran. Aspek yang diukur pada angket ini adalah attention (perhatian), convidence (keyakinan), satisfaction (kepuasan), dan relevance (keterkaitan).

\section{HASIL DAN PEMBAHASAN}

Deskripsi Hasil dan Pembahasan Uji Kevalidan Media beserta Perangkat Perencanaan Pembelajaran (Silabus \& RPP)

Salah satu tujuan pelaksanaan penelitian ini sebagaimana dikemukakan pada pendahuluan adalah dihasilkannya sebuah media smart exploding box berbasis deep dialogue critical thinking beserta perangkat pendukungnya yang valid. Media dan perangkat ini nantinya akan di internalisasikan pada mata pelajaran PKn. Secara bertahap hasil uji kevalidan media dan perangkat pembelajarannya akan di uraikan pada subbab di bawah ini.

\section{Hasil Uji Kevalidan Media}

Uji kevalidan media ini menggunakan dua orang ahli, yaitu ahli media dan ahli materi. Aspek penilaian dari ahli media adalah: (1) Anatomi media, (2) desain dan warna, (3) tampilan menyeluruh. Untuk aspek penilaian ahli materi adalah: (1) Kelayakan materi, (2) keakuratan materi, (3) kemutakhiran materi, (4) kebahasaan, (5) nilai karakter. Hasil uji kevalidan media oleh kedua ahli menunjukan bahwa media ini termasuk dalam kriteria baik ke atas, secara rinci hasil dapat diamati pada table di bawah ini.

Tabel 1. Hasil Penilaian Kevalidan Media oleh Ahli Media

\begin{tabular}{|c|l|c|c|}
\hline No & \multicolumn{1}{|c|}{ Aspek Penilaian } & Total Skor & Kriteria \\
\hline 1. & Anatomi Media & 27,00 & Sangat Baik \\
\hline 2. & Desain dan Warna & 24,00 & Baik \\
\hline 3. & Tampilan Menyeluruh & 25,00 & Baik \\
\hline \multicolumn{2}{|r}{ Rerata } & 25 & Baik \\
\hline
\end{tabular}


Feri, Fidaus, Joko. Pengembangan Media Smart Exploding...

Tabel 2. Hasil Penilaian Kevalidan Materi pada Media oleh Ahli Materi

\begin{tabular}{|c|l|c|c|}
\hline No & \multicolumn{1}{|c|}{ Aspek Penilaian } & Total Skor & Kriteria \\
\hline 1. & Kelayakan Materi & 24,00 & Baik \\
\hline 2. & Keakuratan Materi & 24,00 & Baik \\
\hline 3. & Kemutakhiran Materi & 22,00 & Baik \\
\hline 4. & Kebahasaan & 23,00 & Baik \\
\hline 5. & Nilai Karakter & 28,00 & Sangat Baik \\
\hline \multicolumn{2}{r}{ Rerata } & 24 & Baik \\
\hline
\end{tabular}

Tabel 3. Kriteria Konversi Skor Kuantitatif Ke Penilaian Kualitatif

\begin{tabular}{|c|c|}
\hline \multicolumn{2}{|c|}{ Kriteria Konversi } \\
\hline Skor Kuantitatif & Penilaian Kualitatif \\
\hline $26-30$ & Sangat Baik \\
\hline $20-25$ & Baik \\
\hline $15-19$ & Cukup \\
\hline $10-14$ & Kurang \\
\hline
\end{tabular}

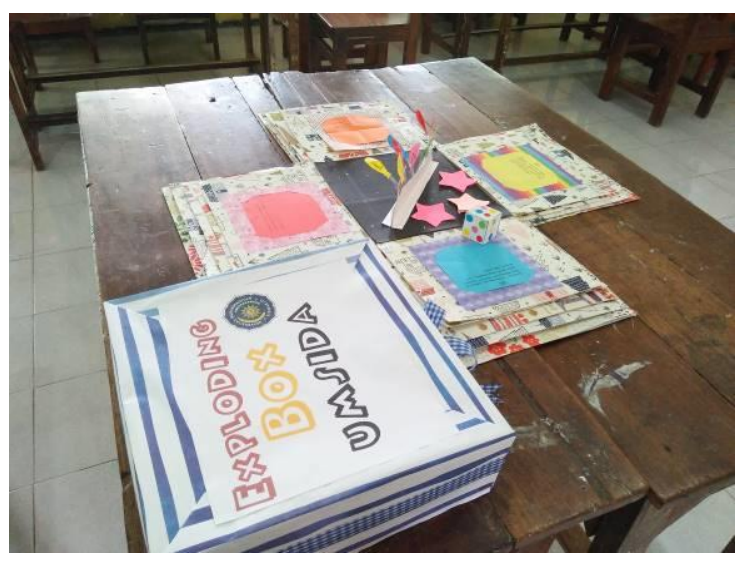

Gambar 1. Media Exploding Box

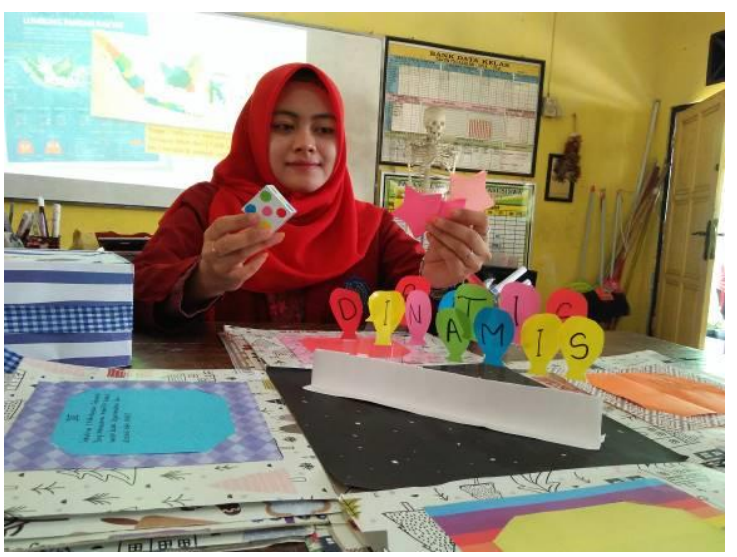

Gambar 2. Penggunaan Media Exploding Box 
Feri, Fidaus, Joko. Pengembangan Media Smart Exploding...

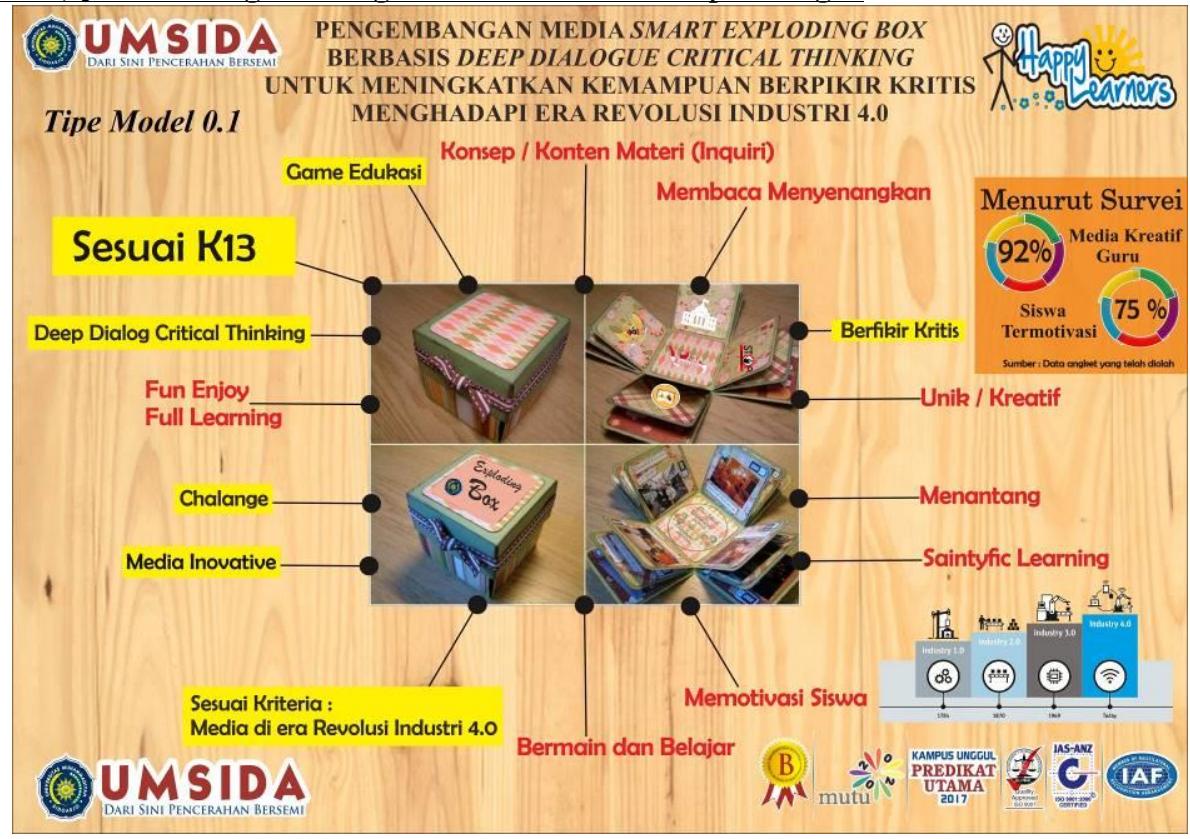

Gambar 3. Spesifikasi Media Exploding Box

\section{Deskripsi Uji Kevalidan Perangkat Pembelajaran Pendukung Media}

Adapun perangkat pendukung media ini adalah (1) Silabus dan Rencana Pelaksanaan Pembelajaran (RPP); (2) buku ajar PKn berbasis Deep Dialogue Critical Thinking (Buku Ajar dan LKS termasuk di dalamnya), dan; (3) Tes Hasil Belajar (THB).

Silabus dan RPP merupakan suatu pedoman yang dirancang secara sistimatik berupa langkah-langkah kegiatan pelaksanaan pembelajaran yang digunakan guru dalam kegiatan belajar mengajar di kelas (Muhammad, 2012). Langkah-langkah pelaksanaan kegiatan pembelajaran dalam RPP ini dituliskan dalam bentuk skenario berupa kegiatan guru dan siswa melalui kegiatan pendahuluan, kegiatan inti, dan penutup, dengan menggunakan media Smart Exploding Box berbasis Deep Dialogue Critical Thinking, sesuai dengan alokasi waktu yang ditetapkan untuk tiap pertemuan. Adapun komponen RPP dalam penelitian ini yakni meliputi: Capaian Pembelajaran, Tujuan Instruksional Umum dan Khusus, indikator, tujuan pembelajaran, pengelolaan pembelajaran, sumber pembelajaran, alat dan bahan, kegiatan belajar mengajar dan penilaian (Suhardan, 2009).

Silabus dan RPP yang dikembangkan dalam penelitian ini dirancang untuk dua kali pertemuan. Pada pertemuan pertama digunakan pada pelaksanaan pembelajaran untuk sub pokok bahasan memahami Peranan warga negara dalam berpartisipasi terhadap pembangunan Nasional di indonesia. 
Feri, Fidaus, Joko. Pengembangan Media Smart Exploding...

Pakar atau ahli akan melakukan validasi pada tiga aspek yaitu isi, bahasa, dan format. Kevalidan perangkat pembelajaran ini divalidasi oleh 2 orang ahli (materi dan media), aspek yang divalidasi oleh kedua ahli adalah aspek kesesuaian perangkat pembelajaran (termasuk buku ajar dan tes hasil belajarnya) (Mulyasa, 2014). Pelaksanaan validasi terhadap perangkat pembelajaran yang telah dikembangkan berupa skor penilaian, koreksi dan saran. Hasil validasi berupa skor penilaian, koreksi dan saran inilah yang akan digunakan sebagai dasar untuk melakukan revisi dan penyempurnaan terhadap perangkat pembelajaran. Hasil revisi kemudian dikonsultasikan dan ditelaah oleh peneliti untuk disempurnakan. Perangkat pembelajaran yang telah dikonsultasikan dan ditelaah oleh validator dan dinyatakan telah sesuai dengan koreksi dan saran validator kemudian disepakati bahwa perangkat pembelajaran valid serta layak digunakan. Berikut hasil uji kevalidan perangkat pembelajaran pendukung media.

Tabel 4. Hasil Uji Kevalidan Perangkat Pembelajaran Pendukung Media

\begin{tabular}{|c|c|c|c|}
\hline No. & Responden & Penilaian & Kategori \\
\hline 1. & Ahli Media & 4.32 & Sangat Layak \\
\hline 2. & Ahli Materi & 4.18 & Sangat Layak \\
\hline
\end{tabular}

Tabel 5. Kriteria Konversi Skor Kuantitatif Ke Penilaian Kualitatif

\begin{tabular}{|c|c|}
\hline \multicolumn{2}{|c|}{ Kriteria Penilaian } \\
\hline $4.00-5.00$ & Sangat Layak \\
\hline $3.00-3.99$ & Baik \\
\hline $2.00-2.99$ & Cukup \\
\hline $1.00-1.99$ & Kurang Layak \\
\hline
\end{tabular}

Deskripsi Hasil Aktivitas, Hasil TKBK, dan Hasil Respon Minat Siswa Selama Menggunakan Media

Media dan perangkat pembelajaran yang telah dikembangkan dan divalidasi oleh pakar atau ahli dan dinyatakan valid/layak digunakan atau diterapkan, maka selanjutnya diimplementasikan dalam kegiatan pembelajaran di SDN Kejaten I Sidoarjo. Hal ini dimaksudkan untuk mengetahui efektifitas penerapan perangkat pembelajaran tersebut. Subjek penelitian untuk menguji aktivitas, TKBK dan respon siswa adalah siswa SD Kelas 5 semester 1 sebanyak 28 siswa pada semester 1 tahun pelajaran 2018/2019. 
Feri, Fidaus, Joko. Pengembangan Media Smart Exploding...

Data hasil penelitian dianalisis menggunakan statistik deskriptif yaitu dalam bentuk rata-rata, proporsi, nilai dan persentase. Berikut ini hasil analisis yang meliputi aktivitas siswa selama kegiatan belajar mengajar, hasil tes kemampuan berfikir kritis, dan respon siswa terhadap pembelajaran mata pelajaran PKn dengan media smart exploding box berbasis deep dialogue critical thinking.

\section{Deskripsi Tingkat Aktivitas Siswa melalui Penggunaan Media}

Aktivitas siswa pada saat pelaksanaan kegiatan belajar mengajar berlangsung dengan penerapan media Smart Exploding Box berbasis Deep Dialogue Critical Thinking diamati oleh dua orang pengamat dengan menggunakan lembar observasi keaktifan. Data hasil analisis aktivitas siswa selama penerapan pembelajaran mata pelajaran PKn dengan media Smart Exploding Box berbasis Deep Dialogue Critical Thinking menunjukkan bahwa siswa terlibat aktif dalam kegiatan pembelajaran. Dengan demikian dapat ditarik kesimpulan bahwa aktivitas yang dilakukan oleh siswa tersebut dapat dikategorikan sebagai aktivitas mengkonstruksi pengetahuan bagi dirinya sendiri atau dengan kata lain merupakan kegiatan pembelajaran berpusat pada siswa. Hasil pengamatan terhadap aktivitas siswa selama kegiatan belajar mengajar pada pertemuan ke-1 dan ke-2, dapat dilihat pada tabel di bawah.

Tabel 6. Hasil Observasi Aktivitas Siswa

\begin{tabular}{|c|c|c|c|c|c|}
\hline \multirow{3}{*}{ No } & \multirow{3}{*}{ Aspek Yang Diamati } & \multicolumn{4}{|c|}{ Pengamatan Aktivitas Siswa } \\
\hline & & \multicolumn{2}{|c|}{\begin{tabular}{|c|} 
Rerata aktivitas \\
siswa satu \\
kelas pada \\
Pertemuan \\
\end{tabular}} & \multirow{2}{*}{$\begin{array}{c}\text { Rerata } \\
\text { Aktivitas } \\
\text { Siswa Satu } \\
\text { Kelas pada } \\
\text { Dua } \\
\text { Pertemuan } \\
\end{array}$} & \multirow[t]{2}{*}{$\begin{array}{c}\text { Persentase } \\
\text { Capaian Aktivitas } \\
\text { Siswa }\end{array}$} \\
\hline & & 1 & 2 & & \\
\hline 1 & Memperhatikan apersepsi dari guru & 3 & 4 & 3,5 & $87,5 \%$ \\
\hline 2 & $\begin{array}{l}\text { Duduk sesuai pada kelompok yang } \\
\text { ditentukan }\end{array}$ & 4 & 3 & 3,5 & $87,5 \%$ \\
\hline 3 & Memperhatikan Bimbingan dari Guru & 4 & 3 & 3,5 & $87,5 \%$ \\
\hline 4 & $\begin{array}{l}\text { Keaktifan saat berinteraksi dengan } \\
\text { Media Exploding Box }\end{array}$ & 3 & 3 & 3 & $75 \%$ \\
\hline 5 & Percaya diri siswa saat presentasi & 3 & 3 & 3 & $75 \%$ \\
\hline 6 & $\begin{array}{l}\text { Menyimpulkan kegiatan pembelajaran } \\
\text { bersama guru }\end{array}$ & 3 & 4 & 3,5 & $87,5 \%$ \\
\hline 7 & Mengerjakan Evaluasi & 4 & 3 & 3,5 & $87,5 \%$ \\
\hline \multicolumn{5}{|c|}{$\begin{array}{l}\text { Rerata Persentase Capaian Aktivitas Siswa Satu Kelas ( } 7 \text { Aspek amatan } \\
\text { selama } 2 \text { pertemuan) }\end{array}$} & $84 \%$ \\
\hline
\end{tabular}


Feri, Fidaus, Joko. Pengembangan Media Smart Exploding...

Dari tabel di atas, dapat diartikan bahwa aktivitas siswa menggunakan media tersebut sangat tinggi, dimana ditunjukkan hasil rerata persentase capaian aktivitas siswa satu kelas (7 aspek amatan selama 2 pertemuan) sejumlah $84 \%$.

\section{Deskripsi Kemampuan Berfikir Kritis Siswa setelah Penggunaan Media}

Media ini adalah seperangkat Draft Desain dan Produk Media Pembelajaran Kreatif dengan Media smart exploding box berbasis deep dialogue critical thinking pada mata pelajaran PKn berserta perangkat pembelajarannya untuk meningkatkan kemampuan berpikir kritis siswa sejalan dengan tuntutan pendidikan di era revolusi industry 4.0. Dimana pengembangan media exploding box berbasis deep dialogue and critical thinking akan dilakukan sampai tahap desain / uji coba dengan sebuah hipotesis bahwa pengembangan media smart exploding box berbasis deep dialogue critical thinking berpengaruh dalam meningkatkan kemampuan berpikir kritis siswa SD di kelas V SDN Ketajen I. Prototipe produk yang dihasilkan yaitu sebuah media smart exploding box berbasis deep dialogue critical thinking yang telah disusun satu paket dengan silabus, RPP dan bahan ajarnya, serta manual guide-nya dimana media ini memiliki berbagai jenis permainan games fun learning yang mampu menarik motivasi siswa agar mampu berdialog dan berinteraksi dengan sesama temannya dalam proses pembelajaran dalam pemikiran yang berlangsung kritis. Adapun rencana didalam penelitian ini nantinya adalah adanya peningkatan ketrampilan berpikir kritis siswa SD kelas $\mathrm{V}$ pada saat proses pembelajaran melalui penggunaan media exploding box berbasis deep dialogue and critical thinking yang dikembangkan melalui petunjuk yang ada pada media . Media exploding box secara umum berbentuk kubus, dan pada kubus tersebut bisa dibuka seperti jaring-jaring bangun datar yang dimasing-masing sisi nya memiliki suatu materi dan konsep bahkan istruksi menggunakan kata bantu pada masing-masing materi yang secara bergantian akan dimainkan saat PBM oleh siswa secara berkelompok.

Tabel 7. Data Hasil Tes Kemampuan Berfikir Kritis Siswa (TKBK)

\begin{tabular}{|c|c|c|}
\hline \multicolumn{2}{|c|}{ Hasil TKBK Klasikal } & \multirow{2}{*}{ Keterangan } \\
\cline { 1 - 2 } Pertemuan Ke-1 & Pertemuan Ke-2 & \\
\hline 74,71 & 81,15 & Tuntas \\
\hline
\end{tabular}


Feri, Fidaus, Joko. Pengembangan Media Smart Exploding...

Dari hasil TKBK dikatakan tuntas apabila proporsi semua hasilnya adalah $\geq 70,00$ ketuntasan tujuan pembelajaran setelah penerapan pembelajaran dengan media exploding box berbasis deep dialogue and critical thinking menunjukkan keberhasilan atau ketuntasan pada siswa.

\section{Deskripsi Respon Minat Siswa setelah Penggunaan Media}

Untuk memperoleh data tentang bagaimana respon siswa setelah penerapan pembelajaran dapat kita lihat pada ringkasan rekapitulasi data tentang hasil analisis respon siswa sebagaimana disajikan pada tabel 8 yang menunjukkan bahwa skor ratarata minat siswa terhadap penerapan pembelajaran mata pelajaran PKn dengan media smart exploding box berbasis deep dialogue critical thinking pada pembelajaran diperoleh hasil yaitu tiga komponen yaitu, Attention (perhatian) skor rata-rata 16,5 (Sangat Baik) artinya yaitu siswa sangat perhatian terhadap media yang digunakan dan merespon sangat baik sebab banyak sekali komponen didalam media yang membuat pembelajaran sangat menarik bagi siswa, Convidence (keyakinan) skor rata-rata 10,5 (Baik) artinya yaitu siswa memiliki keyakinan untuk menjawab pertanyaan dari media pembelajaran dan Satisfaction (kepuasan) skor rata-rata 6,5 (cukup) artinya yaitu siswa memiliki rasa cukup puas terhadap media yang digunakan serta komponen Relevance (keterkaitan) dengan kategori sangat baik dengan skor rata-rata 7,5 (cukup) dan pada uji coba ke II, diperoleh hasil yaitu tiga komponen dengan kategori baik yaitu, Attention (perhatian) skor rata-rata 17,5 (Sangat Baik) artinya yaitu siswa sangat perhatian terhadap media yang digunakan sangat baik sebab siswa sudah mampu memahami cara dan peraturan pada saat memainkan game menggunakan media tersebut. Convidence (keyakinan) skor ratarata 11,0 (Baik) artinya yaitu siswa memiliki keyakinan untuk menjawab pertanyaan dari media pembelajaran sebab siswa dapat memahami semua materi yang terkandung pada media. Satisfaction (kepuasan) skor rata-rata 7,0 (cukup) artinya yaitu siswa memiliki rasa cukup puas terhadap media yang digunakan sebab media ini merupakan hal baru bagi siswa dan menjadikan suasana belajar menjadi lebih aktif dan memudahkan pemahaman materi sebab dikemas dengan menggunakan tersebut, serta komponen Relevance (keterkaitan) dengan kategori sangat baik, dengan skor rata-rata 8 (cukup) artinya antara materi dan media ada 
Feri, Fidaus, Joko. Pengembangan Media Smart Exploding...

keterkaitan yang cukup baik dengan konten materi yang ada pada buku tematik kurikulum K13.

Tabel 8. Data Hasil Respon Minat Siswa Terhadap Penggunaan Media

\begin{tabular}{|l|c|c|c|c|c|}
\hline \multirow{2}{*}{ No } & \multirow{2}{*}{ Aspek Respon } & \multicolumn{4}{|c|}{ Siswa } \\
\cline { 3 - 6 } & & Pertemuan 1 & Kriteria & Pertemuan 2 & Kriteria \\
\hline 1. & Attention (Perhatian) & 16,5 & sangat baik & 17,5 & sangat baik \\
\hline 2. & Convidence (Keyakinan) & 10,5 & baik & 11,0 & baik \\
\hline 3. & Satisfaction (Kepuasan) & 6,5 & cukup & 7,0 & cukup \\
\hline 4. & Relevance (Keterkaitan) & 7,5 & cukup & 8 & cukup \\
\hline
\end{tabular}

Tabel 9. Kriteria Konversi Skor Kuantitatif Ke Penilaian Kualitatif

\begin{tabular}{|c|c|}
\hline \multicolumn{2}{|c|}{ Kriteria Penilaian } \\
\hline Skor Kuantitatif & Penilaian Kualitatif \\
\hline $16-20$ & sangat baik \\
\hline $10-15$ & baik \\
\hline $5-9$ & cukup \\
\hline $0-4$ & kurang \\
\hline
\end{tabular}

\section{SIMPULAN}

Dari hasil dan pembahasan pada bagian di atas, disimpulkan bahwa, media dan perangkat pembelajaran yang dikembangkan pada penelitian ini termasuk dalam kategori valid, dimana hasil kevalidan ahli media mendapatkan skor 25 (baik) dan ahli materi mendapatkan skor 24 (baik).

Berdasarkan hasil uji coba pada pertemuan ke-1 dan ke-2 yang telah dilaksanakan pada penelitian ini ditemukan sebuah data baru bahwa penggunaan media ini pada mata pelajaran PKn pada kelas V SDN Ketajen I Sidoarjo menunjukkan bahwa hasil rerata persentase capaian aktivitas siswa satu kelas (7 aspek amatan selama 2 pertemuan) sangat tinggi, yaitu sejumlah $84 \%$. Kemudian data hasil TKBK sebesar 81,15 (tuntas). Selain itu, media ini juga mendapatkan respon minat siswa yang baik, yaitu pada pertemuan terakhir (ke-2) mendapatkan skor attention (perhatian) sebesar 17,5 (sangat baik), convidence (keyakinan) sebesar 11,0 (baik), satisfaction (kepuasan) sebesar 7,0 (cukup), dan relevance (keterkaitan) sebesar 8 (cukup).

Melalui pengembangan media smart exploding box berbasis deep dialogue critical thinking untuk meningkatkan kemampuan berpikir kritis menghadapi era revolusi industri 4.0 pada mata pelajaran PKn di kelas V SDN Ketajen I Sidoarjo 
Feri, Fidaus, Joko. Pengembangan Media Smart Exploding...

diharapkan bisa menjadikan nilai positif dan menjadikan sebuah nilai plus atau nilai tambah bagi kualitas output lulusan SDN Ketajen I Sidoarjo, sebab siswa yang lulus nantinya tidak hanya terbekali dengan kemampuan akademis dan pedagogis saja, namun juga dibekali oleh sebuah life skill yang berupa kemampuan berpikir kritis yang bermanfaat sebagai ilmu survive atau bekal hidup siswa nantinya agar bisa menciptakan ide peluang usaha industry kreatif dibidang pendidikan sesuai dengan background ilmu siswa yaitu guru.

\section{UCAPAN TERIMAKASIH}

Ucapan terimakasih kami tunjukkan kepada DRPM Universitas Muhammadiyah Sidoarjo yang telah memberikan support dan dukungan kepada tim kami untuk melakukan riset ini. Terima kasih juga untuk sekolah mitra SDN Ketajen I Sidoarjo yang telah memberikan kesempatan kepada kami untuk melakukan riset dan penyempurnaan nya hingga bisa terselesaikan dengan baik.

\section{DAFTAR RUJUKAN}

Suoarman, A, 2014. Teori Belajar dan Pembelajaran. Bogor: Ghalia Indonesia.

Budiningsih. C. A. 2010. Pendekatan Deep Dialogue and Critical Thinking. Jakarta: Universitas Indonesia.

Budi, S.2017. Kemampuan Berfikir Kritis Siswa Sekolah Dasar Di Era Distrubsi Budaya Dan Gadget. Jurnal Lentera Pendidikan: Volume II Tahun 2016.

Mastiono. 2016. PKn di SD tantangan dan inovasi di era Multidimensi. Surakarta: Fairuz Media.

Mulyasa. 2014. Kurikulum 13: Konsep, Karakteristik, dan Implementasi. Bandung: PT. Remaja Rosdakarya.

Sujana, N. 2005. Pembinaan dan Pengembangan Kurikulum Berkarakter Literasi di Sekolah. Jakarta : Sinar Baru Algensindo.

Norris and Ennis. 2007. Inovation Curriculum: Reading for Developing Quality Educational Programs. (Ninth Edition). Boston: Pearson.

Khabibah. 2006. Metodologi Penelitian Kuantitatif. Bandung: PT. Remaja Rosda Karya. 
Feri, Fidaus, Joko. Pengembangan Media Smart Exploding...

Muhammad, R. 2012. Kurikulum Berkarakter Berbasis Critical Thinking. Jakarta: Prestasi Pustakarya.

Suhardan, D. 2009. Manejemen Pendidikan. Bandung: Alfabeta Sutama. 